\title{
ANALISIS MANAJEMEN RISIKO KESELAMATAN DAN KESEHATAN KERJA (K3) PADA PROYEK PEMBANGUNAN GEDUNG DI SEMARANG
}

\author{
Sofiatul Muflihah ${ }^{1^{*}}$, Hari Setijo Pudjihardjo ${ }^{2}$ \\ Jurusan Teknik, Fakultas Teknik, Universitas Semarang \\ Jalan Arteri Soekarno Hatta - Tlogosari - Semarang \\ e-mail : sofiatulmuf24@gmail.com
}

\begin{abstract}
The activity of building construction projects is generally an activity that contains many elements of danger. The situation in the project location reflects a strong character and its activities look very complex and difficult to implement so that it requires excellent stamina from the workers who carry it out. However, it is undeniable that this construction work is a significant contributor to the number of accidents. This research will discuss the factors that influence occupational safety and health, the application of occupational safety and health and occupational safety and health risks with the aim to find out the types of risks, the factors that influence and manage occupational safety and health risk management. building construction projects in semarang. Data analysis was carried out by making questionnaires and distributing questionnaires to 45 respondents. The respondents themselves consist of directors, consultants and contractors. This study concludes that the application of occupational safety and health risk management is very influential in building construction.
\end{abstract}

Keywords : occupational safety and health; risk management; building development project.

\begin{abstract}
ABSTRAK
Aktivitas pembangunan proyek konstruksi bangunan gedung pada umumnya merupakan kegiatan yang sangat komplek dan sangat berbahaya. Kondisi seperti ini menunjukan karakter yang keras dan sulit dilaksanakan, sehingga dibutuhkan tenaga yang sangat kuat dari pekerja. Karena pekekerjaan didalam proyek yang sangat komplek, tidak dapat dipungkiri bahwa dalam proses pelaksanaan kegiatan konstruksi menunjukan angka kecelakaan yang terjadi cukup tinggi. Dalam penelitian ini akan dibahas mengenai faktor - faktor yang mempengaruhi keselamatan dan kesehatan kerja ( K3 ), tindakan penerapan keselamatan dan kesehatan kerja ( K3 ) dan risiko keselamatan dan kesehatan kerja ( K3 ) dengan tujuan untuk mengetahui jenis - jenis risiko, faktor - faktor yang mempengaruhi dan pengelolaan manajemen risiko keselamatan dan kesehatan kerja pada proyek pembangunan gedung di semarang. Analisis data yang dilakukan dengan membuat kuisioner dan penyebaran kuisioner kepada 45 responden. Responden itu sendiri terdiri dari direktur, konsultan dan kontraktor. Penelitian ini simpulkan bahwa penerapan manajemen risiko keselamatan dan kesehatan kerja sangatlah berpengaruh dalam pembangunan gedung.

Kata kunci : keselamatan dan kesehatan kerja; manajemen risiko; proyek pembangunan gedung.
\end{abstract}

\section{PENDAHULUAN}

Kegiatan jasa konstruksi telah terbukti memberikan kontribusi penting dalam perkembangan dan pertumbuhan ekonomi disemua negara di dunia, termasuk Indonesia, baik yang diselenggarakan oleh pemerintah maupun swasta. 
Seperti diketahui kegiatan proyek merupakan permasalahan yang sangat komplek banyak kegiatan kegiatan yang melibatkan banyak tenaga kerja, material dan peralatan berat. Karena dalam pelaksanaan proyek konstruksi ini permasalahan keselamatan dan kesehatan kerja (K3) kurang mendapat perhatian banyak sekali kecelakaan dan penyakit yang terjadi dan menimpa tenaga kerja baik yang ahli maupun terampil. Untuk meminimalkan kecelakaan dan penyakit yang timbul dalam pelaksanaan proyek konstruksi perlu dilakukannya manajemen risiko.

\section{METODE PENELITIAN}

\section{Teknik Pengumpulan Data}

Dalam penelitian ini teknik yang digunakan untuk mengumpulkan data penelitian, yaitu dengan kuisioner sebagai instrument untuk menjawab seperangkat pertanyaan atau pernyataan tertulis kepada responden yang terdiri dari direktur, kontraktor dan konsultan. Kuisioner dibuat dengan menggunakan pertanyaan terbuka, yaitu terdiri dari pertanyaan - pertanyaan untuk menjelaskan identitas responden, dan pertanyaan tertutup, yaitu pertanyaan yang meminta responden untuk memilih salah satu jawaban yang tersedia dari setiap pertanyaan.

\section{Teknik Analisa Data}

Metode statistik yang dipakai dalam penelitian ini disesuaikan dengan sasaran penelitian yang akan dicapai. Setelah data primer diperoleh, maka semua jawaban kuisioner pada semua jawaban menggunakan skala likert 1 - 4, sedangkan metode statistik yang telah digunakan adalah Indeks Kepentingan Relatif (IKR).

$$
\bar{x}=\frac{\sum_{i=1}^{n} \mathrm{Xi}}{n}
$$

Keterangan :

$\bar{x}=$ nilai rata - rata $($ mean $)$

$\mathrm{n}=$ jumlah responden

$\mathrm{Xi}=$ frekuensi pada $(\mathrm{i})$ yang diberikan reponden

Sebagai presentasi jumlah responden terhadap masing - masing permasalahan : $\mathrm{i}=$ kategori indeks responden

Dari hasil data kuisioner tersebut diperbandingkan sebagai koefisien rangking, kemudian dapat ditentukan rangking dari masing - masing faktor dengan cara mengurutkan nilai mean dari yang tertinggi sebagai rangking 1 .

$$
\mathrm{IKR}=\frac{\bar{x}}{m}
$$

$$
\begin{aligned}
& \text { Keterangan : } \\
& \begin{array}{ll}
\text { IKR } \quad=\text { Indeks kepentingan relative } \\
\bar{x} \quad=\text { rata-rata ukuran nilai faktor } \\
\mathrm{m} \quad=4 \text { ( pada faktor yang mempengaruhi })
\end{array}
\end{aligned}
$$

\section{ANALISIS DAN PEMBAHASAN}

Hasil pengisian kuisioner merupakan indikator dari jabatan, usia, pendidikan serta lama responden bekerja. Hasil analisis tersebut tertuang dalam gambar 1 sampai 4. 


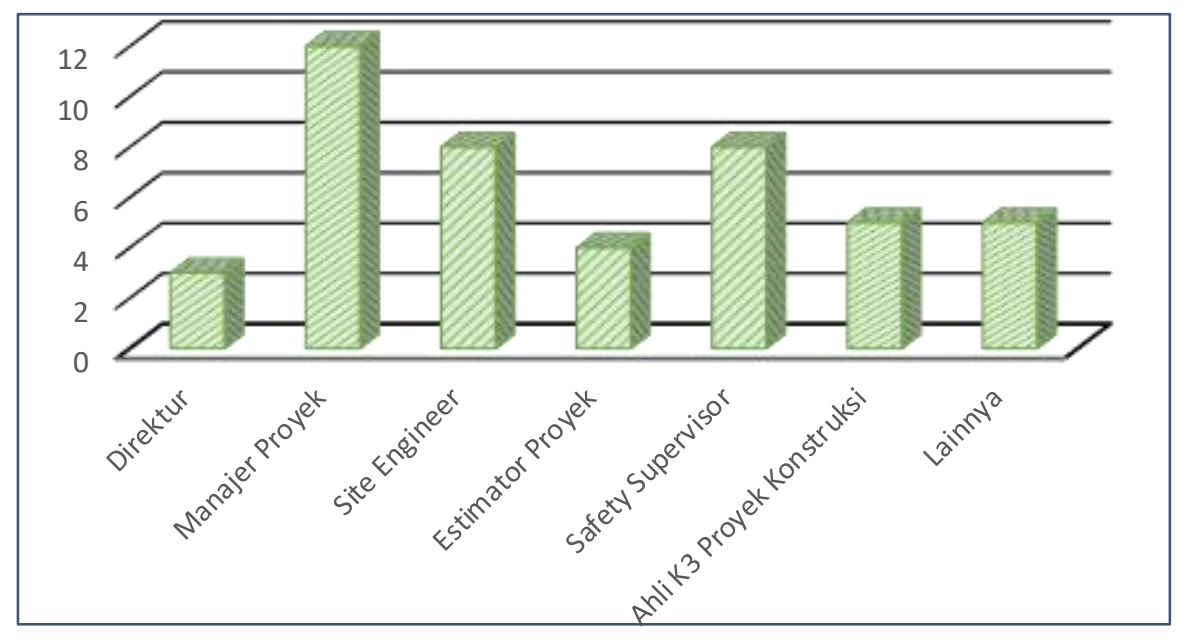

Gambar 1. Jabatan Responden Sumber : Hasil Analisis Peneliti, 2019

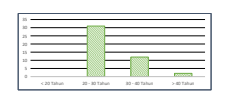

Gambar 2. Jabatan Responden

Sumber : Hasil Analisis Peneliti, 2019

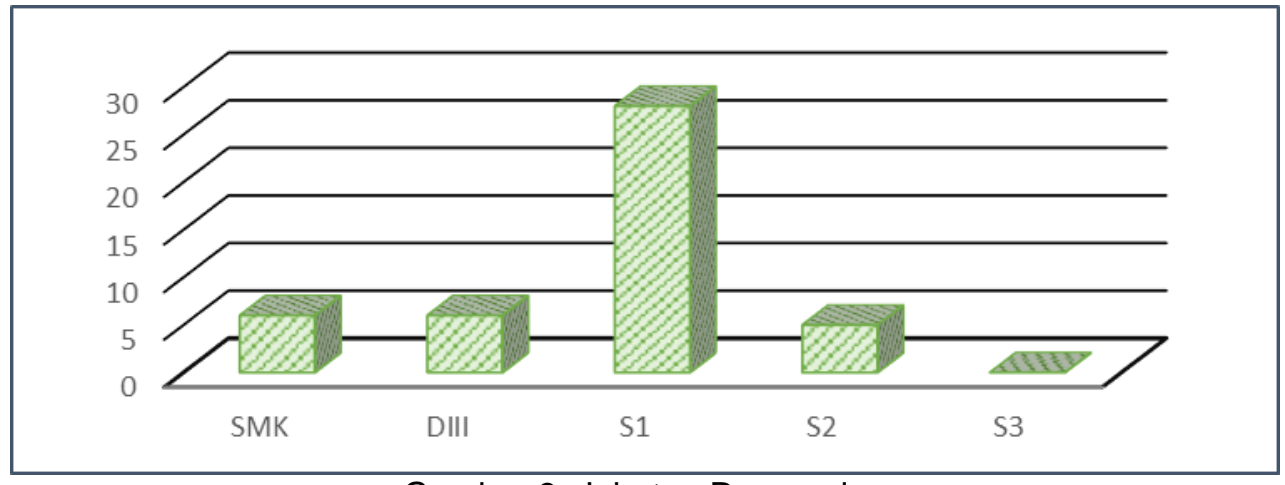

Gambar 3. Jabatan Responden Sumber : Hasil Analisis Peneliti, 2019 


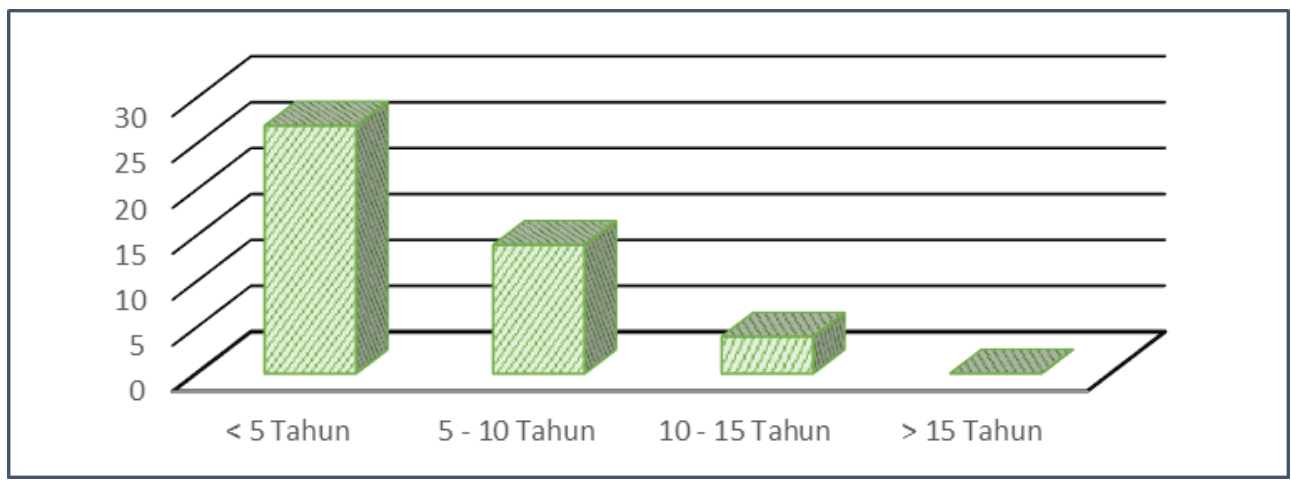

Gambar 4. Jabatan Responden

Sumber : Hasil Analisis Peneliti, 2019

Hasil analisis ranking pada faktor - faktor yang mempengaruhi $\mathrm{K} 3$ dapat dilihat pada tabel 1,2 , dan 4.

Tabel 1. Hasil Rangking Faktor - Faktor yang Mempengaruhi Penerapan K3

\begin{tabular}{|c|c|c|c|c|}
\hline No. & Pertanyaan & Mean & Rank & Ket. \\
\hline 1 & $\begin{array}{l}\text { Kompetensi keahlian dan ketrampilan } \\
\text { pekerja }\end{array}$ & 3.44 & 1 & $\begin{array}{l}\text { Sangat } \\
\text { Berpengaruh }\end{array}$ \\
\hline 2 & Kondisi Fisik & 3.42 & 2 & $\begin{array}{l}\text { Sangat } \\
\text { Berpengaruh }\end{array}$ \\
\hline 3 & Pelatihan dan ketrampilan & 3.36 & 3 & $\begin{array}{l}\text { Sangat } \\
\text { Berpengaruh }\end{array}$ \\
\hline 4 & Keadaan Lingkungan Kerja & 3.33 & 4 & $\begin{array}{l}\text { Sangat } \\
\text { Berpengaruh }\end{array}$ \\
\hline 5 & Kondisi Psikologis & 3.31 & 5 & $\begin{array}{l}\text { Sangat } \\
\text { Berpengaruh }\end{array}$ \\
\hline 6 & Kondisi Fisiologis & 3.29 & 6 & $\begin{array}{l}\text { Sangat } \\
\text { Berpengaruh }\end{array}$ \\
\hline 7 & $\begin{array}{l}\text { Banyak pekerja beranggapan bahwa } \\
\text { Keselamatan dan Kesehatan Kerja ( K3 ) } \\
\text { tidak penting dan mengganggu kebebasan } \\
\text { bergerak dalam pelaksanaan proyek } \\
\text { konstruksi ( kesadaran yang kurang ) }\end{array}$ & 3.27 & 7 & $\begin{array}{l}\text { Sangat } \\
\text { Berpengaruh }\end{array}$ \\
\hline 8 & $\begin{array}{l}\text { Kesadaran para pekerja proyek yang } \\
\text { rendah akan terjadinya kecelakaan }\end{array}$ & 3.24 & 8 & Berpengaruh \\
\hline 9 & Minimnya keahlian para pekerja proyek & 3.22 & 9 & Berpengaruh \\
\hline 10 & $\begin{array}{l}\text { Peralatan Alat Pelindung Diri ( APD ) yang } \\
\text { tidak mempunyai standar SNI sehingga } \\
\text { sering terjadi kerusakan }\end{array}$ & 3.18 & 10 & Berpengaruh \\
\hline 11 & $\begin{array}{l}\text { Kurangnya pengetahuan mengenai } \\
\text { Keselamatan dan Kesehatan Kerja ( K3 ) }\end{array}$ & 3.09 & 11 & Berpengaruh \\
\hline 12 & $\begin{array}{l}\text { Para pekerja tidak mengetahui bahaya dan } \\
\text { resiko pekerjaan yang dilakukannya }\end{array}$ & 3.07 & 12 & Berpengaruh \\
\hline
\end{tabular}




\begin{tabular}{|c|c|c|c|c|}
\hline 13 & Keadaan Tenaga Kerja (tingkat pendidikan) & 3.04 & 13 & Berpengaruh \\
\hline 14 & $\begin{array}{l}\text { Bersendau gurau pada saat melakukan } \\
\text { pekerjaan yang berbahaya. }\end{array}$ & 3.02 & 14 & Berpengaruh \\
\hline 15 & $\begin{array}{l}\text { Petunjuk, pengarahan dan rambu - rambu } \\
\text { Keselamatan dan Kesehatan Kerja (K3) } \\
\text { yang di abaikan }\end{array}$ & 3 & 15 & Berpengaruh \\
\hline 16 & Tindakan perbaikan & 2.98 & 16 & Berpengaruh \\
\hline 17 & $\begin{array}{l}\text { Komitment dan dukungan manajemen } \\
\text { puncak }\end{array}$ & 2.96 & 17 & Berpengaruh \\
\hline 18 & Persiapan dan Respon tanggap darurat & 2.93 & 18 & Berpengaruh \\
\hline 19 & $\begin{array}{l}\text { Kurangnya komunikasi antar pekerja } \\
\text { sehingga para pekerja tidak saling } \\
\text { mengingatkan pada saat pekerja } \\
\text { melakukan pekerjaan yang mempunyai } \\
\text { resiko level bahaya }\end{array}$ & 2.91 & 19 & Berpengaruh \\
\hline 20 & $\begin{array}{l}\text { Tidak adanya sanksi terhadap pekerja } \\
\text { proyek yang melanggar peraturan } \\
\text { Keselamatan dan Kesehatan Kerja ( K3 ) }\end{array}$ & 2.89 & 20 & Berpengaruh \\
\hline 21 & $\begin{array}{l}\text { Kurangnya rambu - rambu aturan } \mathrm{K} 3 \mathrm{di} \\
\text { area proyek }\end{array}$ & 2.87 & 21 & Berpengaruh \\
\hline 22 & $\begin{array}{l}\text { Tidak nyaman saat memakai peralatan Alat } \\
\text { Pelindung Diri ( APD ) }\end{array}$ & 2.84 & 22 & Berpengaruh \\
\hline 23 & $\begin{array}{l}\text { Biaya untuk penyediaan Alat Pelindung Diri } \\
\text { (APD) }\end{array}$ & 2.82 & 23 & Berpengaruh \\
\hline 24 & Pemantauan dan Pengukuran kerja & 2.8 & 24 & Berpengaruh \\
\hline 25 & $\begin{array}{l}\text { Ketidaksesuaian peralatan yang dipakai } \\
\text { dengan pekerjaan yang akan dilaksanakan }\end{array}$ & 2.78 & 25 & Berpengaruh \\
\hline 26 & $\begin{array}{l}\text { Pengendalian Dokumen Keselamatan dan } \\
\text { Kesehatan Kerja ( K3 ) }\end{array}$ & 2.76 & 26 & Berpengaruh \\
\hline 27 & $\begin{array}{l}\text { Metode dan Cara Kerja terkait dengan } \\
\text { kemajuan teknologi }\end{array}$ & 2.73 & 27 & Berpengaruh \\
\hline 28 & Penyelidikan Insiden & 2.56 & 28 & Berpengaruh \\
\hline 29 & $\begin{array}{l}\text { Kecelakaan kerja lebih sering terjadi pada } \\
\text { shift malam dari pada shift pagi ataupun } \\
\text { sore }\end{array}$ & 2.51 & 29 & Berpengaruh \\
\hline 30 & $\begin{array}{l}\text { Peraturan dan prosedur Keselamatan dan } \\
\text { Kesehatan Kerja ( K3 ) yang sulit di } \\
\text { mengerti }\end{array}$ & 2.49 & 30 & $\begin{array}{l}\text { Kurang } \\
\text { Berpengaruh }\end{array}$ \\
\hline 31 & Audit internal & 2.31 & 31 & $\begin{array}{l}\text { Kurang } \\
\text { Berpengaruh }\end{array}$ \\
\hline
\end{tabular}


(Sumber : Hasil Analisis Peneliti, 2019)

Dari hasil analisis pengisian kuisioner yang diperoleh dari Responden terkait dengan factor factor penerapan K3 ternyata yang sangat berpengaruh atau sangat dominan adalah Kompetensi keahlian dan ketrampilan pekerja, Kondisi Fisik, Pelatihan dan ketrampilan, Keadaan Lingkungan Kerja, Kondisi Psikologis, Kondisi Fisiologis dan Kesadaran pekerja akan pentingnya Keselamatan dan Kesehatan Kerja ( K3 ).

Tabel 2. Hasil Rangking Penerapan Keselamatan dan Kesehatan Kerja (K3)

\begin{tabular}{|c|c|c|c|c|}
\hline NO. & Pertanyaan & Mean & Rank & Ket. \\
\hline \multirow[t]{5}{*}{1} & $\begin{array}{l}\text { Jaminan Kemampuan: } \\
\text { a. Pelatihan dan Keterampilan }\end{array}$ & 1.67 & 1 & Dilaksanakan \\
\hline & b. Tanggung jawab dan tanggung gugat. & 1.76 & 2 & $\begin{array}{l}\text { Tidak } \\
\text { Dilaksanakan } \\
\text { Sepenuhnya }\end{array}$ \\
\hline & $\begin{array}{l}\text { C. Sumber daya manusia, fisik dan } \\
\text { financial }\end{array}$ & 1.84 & 3 & $\begin{array}{l}\text { Tidak } \\
\text { Dilaksanakan } \\
\text { Sepenuhnya }\end{array}$ \\
\hline & d. Konsultasi, Motivasi dan Kesadaran & 1.91 & 4 & $\begin{array}{l}\text { Tidak } \\
\text { Dilaksanakan } \\
\text { Sepenuhnya }\end{array}$ \\
\hline & e. Integrasi & 2.22 & 5 & $\begin{array}{l}\text { Tidak } \\
\text { Dilaksanakan } \\
\text { Sepenuhnya }\end{array}$ \\
\hline \multirow{6}{*}{2} & $\bar{x}$ & \multicolumn{3}{|c|}{1.88} \\
\hline & $\begin{array}{l}\text { Dukungan Tindakan: } \\
\text { a. Pengendalian Dokumen }\end{array}$ & 1.64 & 1 & Dilaksanakan \\
\hline & b. Pencatatan Manajemen Operasi & 1.71 & 2 & Dilaksanakan \\
\hline & c. Pelaporan & 1.76 & 3 & $\begin{array}{l}\text { Tidak } \\
\text { Dilaksanakan } \\
\text { Sepenuhnya }\end{array}$ \\
\hline & d. Komunikasi & 1.87 & 4 & $\begin{array}{l}\text { Tidak } \\
\text { Dilaksanakan } \\
\text { Sepenuhnya }\end{array}$ \\
\hline & e. $\quad$ Dokumentasi & 1.91 & 5 & $\begin{array}{l}\text { Tidak } \\
\text { Dilaksanakan } \\
\text { Sepenuhnya }\end{array}$ \\
\hline \multicolumn{2}{|r|}{$\bar{x}$} & \multicolumn{3}{|c|}{1.77} \\
\hline \multirow[t]{7}{*}{3} & $\begin{array}{l}\text { Identifikasi Sumber Bahaya dan } \\
\text { Pengendalian Resiko: } \\
\text { a. Instruksi Keselamatan Kerja }\end{array}$ & 1.67 & 1 & Dilaksanakan \\
\hline & b. Tindakan Pengendalian & 1.71 & 2 & Dilaksanakan \\
\hline & c. Identifikasi Sumber Bahaya & 1.73 & 3 & Dilaksanakan \\
\hline & d. Penilaian Resiko & 1.78 & 4 & $\begin{array}{l}\text { Tidak } \\
\text { Dilaksanakan } \\
\text { Sepenuhnya }\end{array}$ \\
\hline & e. Tinjauan Ulang Kontrak & 1.8 & 5 & $\begin{array}{l}\text { Tidak } \\
\text { Dilaksanakan } \\
\text { Sepenuhnya }\end{array}$ \\
\hline & f. $\quad$ Prosedur Rencana Pemulihan & 1.82 & 6 & $\begin{array}{l}\text { Tidak } \\
\text { Dilaksanakan } \\
\text { Sepenuhnya }\end{array}$ \\
\hline & g. Prosedur Menghadapi Insiden & 1.89 & 7 & $\begin{array}{l}\text { Tidak } \\
\text { Dilaksanakan } \\
\text { Sepenuhnya }\end{array}$ \\
\hline
\end{tabular}




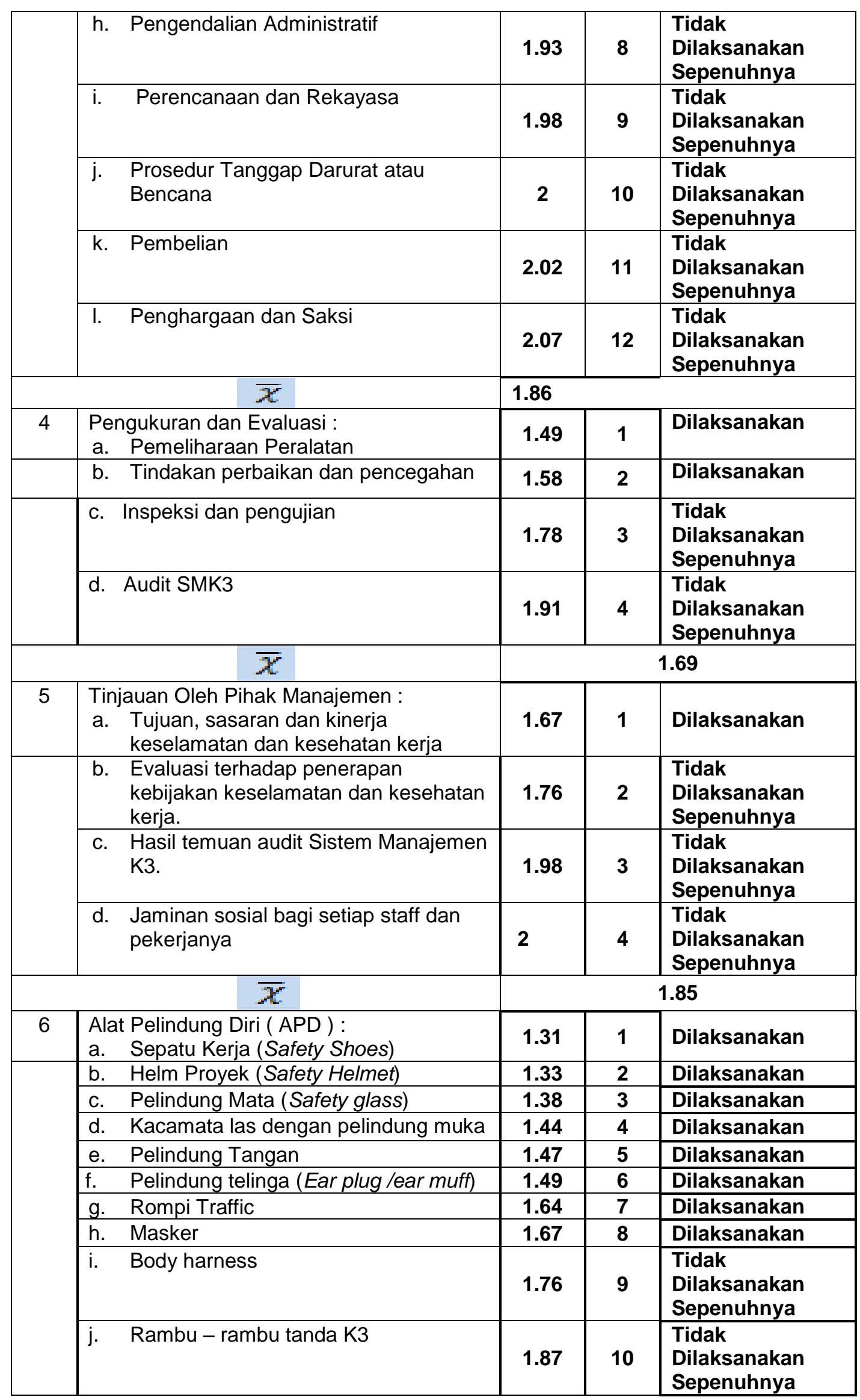




\begin{tabular}{|c|c|c|c|}
\hline k. Jas hujan & 2 & 11 & $\begin{array}{l}\text { Tidak } \\
\text { Dilaksanakan } \\
\text { Sepenuhnya }\end{array}$ \\
\hline I. $\quad$ Pelindung dada & 2,02 & 12 & $\begin{array}{l}\text { Tidak } \\
\text { Dilaksanakan } \\
\text { Sepenuhnya }\end{array}$ \\
\hline $\bar{X}$ & \multicolumn{3}{|c|}{1.70} \\
\hline
\end{tabular}

(Sumber : Hasil Analisis Peneliti, 2019)

Dari hasil analisis pengisian kuisioner yang diperoleh dari Responden terkait dengan Penerapan Keselamatan dan Kesehatan Kerja (K3) ternyata yang dilaksanakan adalah . Pelatihan dan Keterampilan, Pengendalian Dokumen, Pencatatan Manajemen Operasi, Instruksi Keselamatan Kerja, Identifikasi Sumber Bahaya, Pemeliharaan Peralatan, Tindakan perbaikan dan pencegahan, Tujuan, sasaran dan kinerja keselamatan dan kesehatan kerja, Sepatu Kerja (Safety Shoes), Helm Proyek (Safety Helmet), Pelindung Mata (Safety glass), Kacamata las dengan pelindung muka, Pelindung Tangan, Pelindung telinga (Ear plug /ear muff), Rompi Traffic, Masker

Tabel 3. Hasil Rangking Risiko Keselamatan dan Kesehatan Kerja (K3)

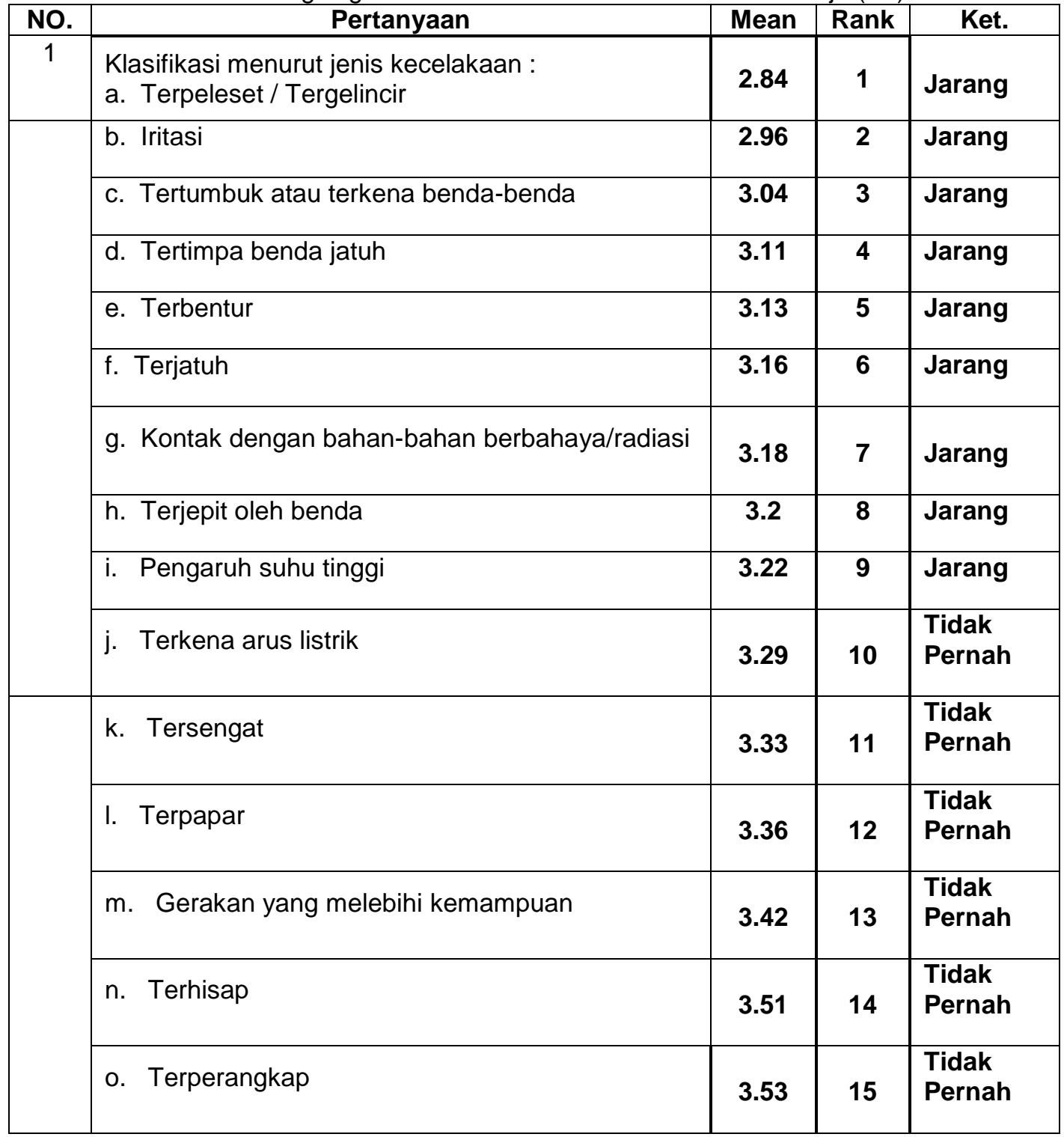




\begin{tabular}{|c|c|c|c|c|}
\hline 2 & $\begin{array}{l}\text { Penyebab terjadinya kecelakaan: } \\
\text { a. Penggunaan peralatan yang menggunakan } \\
\text { Mesin }\end{array}$ & 3.04 & 1 & Jarang \\
\hline & $\begin{array}{l}\text { b. Kondisi kerja di luar bangunan, di dalam } \\
\text { bangunan dan di bawah tanah }\end{array}$ & 3.09 & 2 & Jarang \\
\hline & c. Alat angkut dan angkat : darat, udara, air & 3.24 & 3 & Jarang \\
\hline & $\begin{array}{l}\text { d. Bahan-bahan,zat-zat dan radiasi, misalnya } \\
\text { bahan peledak, gas, zat kimia }\end{array}$ & 3.36 & 6 & $\begin{array}{l}\text { Tidak } \\
\text { Pernah }\end{array}$ \\
\hline 3 & $\begin{array}{l}\text { Jenis luka yang terjadi pada kecelakaan } \\
\text { pelaksanaan proyek: } \\
\text { a. Cedera lainnya }\end{array}$ & 2.71 & 1 & Jarang \\
\hline & b. Terkilir & 2.73 & 2 & Jarang \\
\hline & c. Luka-luka luar & 2.78 & 3 & Jarang \\
\hline & d. Pengaruh cuaca & 2.84 & 4 & Jarang \\
\hline & e. Luka-luka lainnya & 2.87 & 5 & Jarang \\
\hline & f. Memar dan remuk & 3.07 & 6 & Jarang \\
\hline & g. Sesak nafas & 3.09 & 7 & Jarang \\
\hline & h. Akibat arus listrik & 3.2 & 8 & Jarang \\
\hline & i. Dislokasi & 3.29 & 9 & $\begin{array}{l}\text { Tidak } \\
\text { Pernah }\end{array}$ \\
\hline & j. Fraktur / retak & 3.33 & 10 & $\begin{array}{l}\text { Tidak } \\
\text { Pernah }\end{array}$ \\
\hline & k. Akibat radiasi & 3.58 & 11 & $\begin{array}{l}\text { Tidak } \\
\text { Pernah }\end{array}$ \\
\hline & I. Luka majemuk berlainan & 3.6 & 12 & $\begin{array}{l}\text { Tidak } \\
\text { Pernah }\end{array}$ \\
\hline & m. Terbakar & 3.69 & 13 & $\begin{array}{l}\text { Tidak } \\
\text { Pernah }\end{array}$ \\
\hline & n. Gegar otak dan luka dalam lainnya & 3.78 & 14 & $\begin{array}{l}\text { Tidak } \\
\text { Pernah }\end{array}$ \\
\hline & o. Keracunan akut & 3.76 & 15 & $\begin{array}{l}\text { Tidak } \\
\text { Pernah }\end{array}$ \\
\hline & p. Amputasi & 3.82 & 16 & $\begin{array}{l}\text { Tidak } \\
\text { Pernah }\end{array}$ \\
\hline 4 & $\begin{array}{l}\text { Klasifikasi menurut letak kecelakaan / luka tubuh: } \\
\text { a. Anggota bawah }\end{array}$ & 2.98 & 1 & Jarang \\
\hline
\end{tabular}




\begin{tabular}{|l|l|cc|l|}
\hline b. Badan & 3.04 & 2 & Jarang \\
\hline c. Anggota atas & 3.18 & 3 & Jarang \\
\hline d. Banyak tempat & 3,22 & 5 & Jarang \\
\hline e. Kepala & 3,24 & 6 & Jarang \\
\hline f. leher & 3.27 & 7 & Jarang \\
\hline
\end{tabular}

(Sumber : Hasil Analisis Peneliti, 2019)

Dari hasil analisis pengisian kuisioner yang diperoleh dari responden terkait dengan resiko Keselamatan dan Kesehatan Kerja (K3) ternyata pernyataan yang ada pada tabel 4.7 jarang dan tidak pernah terjadi.

\section{KESIMPULAN}

Dari hasil analisis data ternyata penerapan Keselamatan dan Kesehatan Kerja (K3) dipengaruhi oleh kompetensi keahlian / ketrampilan pekerja, kondisi (fisik, psikologis, dan fisiologis), pelatihan dan ketrampilan, keadaan lingkungan kerja. Untuk Penerapan Keselamatan dan Kesehatan Kerja (K3) dari ke 6 pertanyaan yang paling dilaksanakan yaitu dalam Pengukuran dan Evaluasi seperti : pemeliharaan peralatan, tindakan perbaikan (pencegahan), audit SMK3, inspeksi dan pengujian, serta Alat Pelindung Diri ( APD ) yang meliputi : sepatu kerja, helm proyek pelindung mata, kacamata las dengan pelindung muka, pelindung tangan dan telingga, rompi traffic, dan masker, body harnes, rambu rambu dan tanda K3, jas hujan, dan pelindung dada. Dan Pada Risiko K3 yang Terjadi di Lokasi Proyek, Menurut jenis kecelakaan, penyebab, berdasarkan jenis luka-luka dan letak kecelakaan masing - masing jarang dan tidak ternah terjadi di lokasi proyek.

\section{DAFTAR PUSTAKA}

Hakim, A.R. (2017). Implementasi Manajemen Risiko Sistem Kesehatan, Keselamatan Kerja dan Lingkungan (K3l) pada Pembangunan Flyover Pegangsaan 2 Kelapa Gading Jakarta Utara : Media Komunikasi Teknik Sipil (MKTS), Vol. 23, No. 2.

Salawati, Liza, 2015. Penyakit Akibat Kerja dan Pencegahan : Jurnal Kedokteran Syiah Kuala Vol. 15 No. 2

Sepang dan Bryan A. W. (2013). Manajemen Risiko Keselamatan dan Kesehatan Kerja (K3) pada Proyek Pembangunan Ruko Orlens Fashion Manado: Jurnal Sipil Statik, Vol.1, No.4.

Soputan, G.E.M. (2014). Manajemen Risiko Kesehatan dan Keselamatan Kerja (K3) (Study Kasus pada Pembangunan Gedung SMA Eben Haezar) : Jurnal Ilmiah Media Engineering, Vol.4, No.4.

Sucita, I.K., dan Broto, A.A. (2011). Indentifikasi dan Penanganan Risiko K3 pada Proyek Konstruksi Gedung (Studi kasus : Proyek Gedung Centro City Recidences), Jurnal Poli Teknologi, Vol.10, No.1. 
Tagueha, W.P. (2018). Manajemen Resiko Keselamatan dan Kesehatan Kerja (K3) pada Proyek Konstruksi (Studi Kasus: Pembangunan Gedung Laboratorium Fakultas Teknik Unsrat), Jurnal Sipil Statik, Vol.6, No.11. 